https://nv.nltu.edu.ua

https://doi.org/10.15421/40281019

$@ \bowtie$ Correspondence author

Article received 09.11.2018 p.

Article accepted 29.11.2018 p.

I. Yu. Popadiuk

УдК 628.212.2

popaduk_i@ukr.net

В. М. Жук, Л. І. Вовк, I. І. Матлай, І. Ю. Попадюк

Національний університет "Львівська політехніка", м. Львів, Україна

\title{
ВЗАЄМОЗВ'ЯЗОК МІЖ ЗАГАЛЬНИМИ ТА ЕФЕКТИВНИМИ ВОДОНЕПРОНИКНИМИ ПОКРИТТЯМИ ПІД ЧАС МОДЕЛЮВАННЯ ДОЩОВОГО ВОДОВІДВЕДЕННЯ
}

\begin{abstract}
На прикладі житлового кварталу по вул. Широкій у Львові підтверджено важливість поділу загальних водонепроникних покриттів на напряму приєднані до міської каналізаційної мережі (ефективні), водонепроникні покриття та не приєднані водонепроникні покриття. На підставі аналізу та узагальнення результатів дослідження мікрорайонів Денвера (США) (Alley \& Veenhuis, 1983) та території Маріон Каунті (США) (Yang et all., 2011) отримано узагальнені степеневі залежності частки ефективних водонепроникних покриттів $p_{\text {eff }}$ від частки загальних водонепроникних покриттів $p_{t o t}$. Для житлового кварталу по вул. Широкій у м. Львові виконано дослідження розподілу типів покриття за трьома методами: камеральний аналіз розподілу поверхонь за типами покриття на базі супутникових зображень місцевості; натурне обстеження території кварталу 3 уточненням меж покриттів різних типів; натурне обстеження зі встановленням особливостей приєднання різних ділянок до централізованої мережі водовідведення. Порівняно розподіл площ із різними типами покриття та значення загального коефіцієнта стоку $\psi_{0}$, отримані за трьома описаними в роботі методами. Внаслідок проведення натурного обстеження житлового кварталу Львова за значення частки загальних водонепроникних покриттів $p_{t o t}=0,546$ отримано частку ефективних водонепроникних покриттів $p_{\text {eff }}=0,394$, що в 1,08 та в 1,18 раза менше, ніж за формулами, отриманими відповідно для Денвера та території Маріон Каунті.
\end{abstract}

Ключові слова: поверхневий стік; загальні водонепроникні покриття; ефективні водонепроникні покриття; загальний коефіцієнт стоку.

Вступ. Невпинна урбанізація спричиняе відчутні зміни кругообігу води в природі. На 2005 р. сумарна площа забудованих територій у світі становить близько 3 \% від загальної площі суходолу Землі (Laconte \& Gossop, 2016). Зміна природної поверхні грунту на водонепроникні вдосконалені покриття зумовлює зміну їх гідрологічних характеристик, таких як: коефіцієнт стоку, еквівалентна шорсткість, коефіцієнт фільтрації та ін. Це призводить до значних змін характеристик дощового стоку - зменшення часу концентрації потоку, зростання розрахункових витрат та об'ємів стоку, що спричиняє збільшення частоти затоплення забудованих територій (Tkachuk \& Zhuk, 2012).

Важливим етапом моделювання систем дощового водовідведення є докладний аналіз поверхні урбанізованого басейну стоку з визначенням розрахункових характеристик покриття. В Україні розрахункові об'єми поверхневого стоку з урбанізованих територій визначають за нормативним документом (Pravyla korystuvannia, 2008), який розрізняє 4 різних типи покриттів: 1) покрівлі будинків і споруд, асфальтобетонні покриття; 2) бруковані або щебеневі мостові; 3) райони без до- рожніх покриттів, сквери і бульвари; 4) газони. Під час практичної реалізації такого підходу виникають проблеми з трудомісткістю та коректністю визначення площ територій з різними типами покриття, а відповідні бази даних відсутні навіть для найбільших міст України (Zhuk \& Matlai, 2010).

У світовій практиці для моделювання кількості та якості поверхневого стоку з урбанізованих територій найчастіше використовують програмний комплекс SWMM (James \& Rossman, 2010), у якому під час опису типів покриття кварталів використовують лише один кількісний параметр - частка водонепроникних покриттів, тобто загальну площу урбанізованого басейну стоку поділяють на водонепроникну та водопроникну частини. Водночас для водопроникної частини задають цілий набір інфільтраційних параметрів, що дають змогу враховувати зміну інтенсивності інфільтрації в часі в процесі водонасичення грунту. Перспективним напрямом удосконалення якості гідрологічного моделювання дощового стоку з урбанізованих територій є використання GIS-програм та відповідних баз даних (Sanzana et al., 2017).

Інформація про авторів:

Жук Володимир Михайлович, канд. техн. наук, доцент, кафедра гідравліки та сантехніки. Email: zhuk_vm@ukr.net

Вовк Леся Іванівна, канд. техн. наук, ст. викладач, кафедри гідравліки та сантехніки. Email: lesya_v_@ukr.net; https://orcid.org/0000-0001-5396-301X

Матлай Іван Іванович, канд. техн. наук, ст. викладач, кафедри гідравліки та сантехніки. Email: i.matlay@gmail.com

Попадюк Ігор Юрійович, канд. техн. наук, доцент, кафедра гідравліки та сантехніки. Email: popaduk_i@ukr.net

Цитування за ДСтУ: Жук В. М., Вовк Л. І., Матлай І. І., Попадюк І. Ю. Взаємозв'язок між загальними та ефективними водонепроникними покриттями під час моделювання дощового водовідведення. Науковий вісник НЛТУ України. 2018, т. 28, № 10. C. 92-95.

Citation APA: Zhuk, V. M., Vovk, L. I., Matlai, I. I., \& Popadiuk, I. Yu. (2018). Correlation between the total and effective imperviousness in stormwater modelling. Scientific Bulletin of UNFU, 28(10), 92-95. https://doi.org/10.15421/40281019 
Подальше вивчення проблематики моделювання дощового стоку зводиться до більш докладного аналізу водонепроникних поверхонь басейну стоку за типом їх приєднання до дощової водовідвідної мережі. Загальну площу водонепроникних поверхонь зазвичай поділяють на напряму приєднані до мережі водонепроникні покриття або так звані ефективні водонепроникні покриття (ЕВнП) та не приєднані до мережі водонепроникні покриття (НВнП) (Alley \& Veenhuis, 1983; Lee \& Heaney, 2003).

У роботі (Alley \& Veenhuis, 1983) на підставі аналізу та узагальнення результатів дослідження 19 високоурбанізованих мікрорайонів Денвера (США) отримано узагальнену формулу, що пов'язує частку загальних водонепроникних покриттів (ЗВнП) та ЕВнП:

$$
p_{\text {eff }}=p_{\text {tot }}^{1,41} \text {, }
$$

де $p_{e f f}, p_{t o t}-$ відповідно частка ефективних та загальних водонепроникних покриттів у загальній площі території урбанізованого басейну стоку. Коефіцієнт детермінованості для залежності (1) становить $R^{2}=0,98$.

Оброблення натурних даних, наведених у праці (Yang, Bowling, Cherkauer \& Pijanowski, 2011), для території Маріон Каунті (США), що складається зі 100 однакових ділянок загальною площею 900 км², дала змогу отримати апроксимаційну степеневу залежність

$$
p_{\text {eff }}=p_{\text {tot }}^{1,259},
$$

3 невисоким значенням коефіцієнта детермінованості $R^{2}=0,873$, що зумовлено великим розкидом натурних значень, особливо для басейнів із низьким та середнім ступенями урбанізації, тобто в діапазоні значень $p_{t o t} \leq 0,4$ (рис. 2).

У роботі (Zhuk, 2018) вдосконалено статистичний метод камерального визначення відсотка ЗВнП. Безпосереднє застосування залежностей (1) чи (2) для визначення частки ЕВнП може бути некоректним через icтотні відмінності містобудівних норм і практик у різних країнах світу. 3 огляду на докладного вивчення і аналізу потребує отримання взаємозв'язків між частками загальних та ефективних водонепроникних покриттів для міст і селищ України. Отримання залежностей, аналогічних до (1)-(2), дасть змогу істотно зменшити трудовитрати на польові дослідження 3 визначення типів покриття урбанізованих басейнів стоку та підвищити рівень достовірності відповідних гідрологічно-гідравлічних моделей.

Метою роботи є визначення взаємозв'язку між частками загальних та ефективних водонепроникних покриттів під час моделювання дощового водовідведення 3 території типового житлового кварталу по вул. Широкій у м. Львові.

Для реалізації мети було вирішено такі завдання:

- виконано камеральний аналіз розподілу поверхонь за типами покриття для досліджуваного типового житлового кварталу м. Львова на базі супутникових зображень місцевості;

- уточнено границі ділянок із різними типами поверхневого покриття за результатами натурного обстеження території кварталу;

- встановлено особливості приєднання різних ділянок до централізованої мережі водовідведення;

• проаналізовано зміну співвідношення між площами водопроникних та водонепроникних покриттів після використання різних методів;
- отримано взаємозв'язок між частками загальних та ефективних водонепроникних покриттів для типового житлового кварталу м. Львова.

Об'єкт і методи дослідження. Об'єктом дослідження було вибрано типовий квартал багатоповерхової житлової забудови в західній частині м. Львова в межах вулиць Широка-Гніздовського-Вигоди із загальною площею в осях вулиць 7,23 га. Це - район типової житлової забудови 1960-1970-х років. У кварталі з периметрально-блокованим типом забудови розміщені дев'ять типових п'ятиповерхових будинків прямокутної форми, один чотирьохповерховий та сім-двоповерхових житлових будинків. П'ятиповерхові будинки, розташовані по периметру кварталу, мають плоскі дахи та оснащені внутрішніми водостоками, напряму приєднаними до системи каналізації міста. У глибині кварталу розташовані будівлі зі скатними дахами, обладнані зовнішніми водостічними ринвами, що відводять дощовий стік безпосередньо на прилеглу поверхню.

Для вибраного кварталу було виконано дослідження розподілу типів покриття за трьома методами: № 1 - камеральний аналіз розподілу поверхонь за типами покриття на базі супутникових зображень місцевості; № 2 - натурне обстеження території кварталу з уточненням меж покриттів різних типів; № 3 - натурне обстеження зі встановленням особливостей приєднання різних ділянок до централізованої мережі водовідведення.

Результати дослідження. Перший метод полягав у обробці супутникових зображень території кварталу 3 сервісу Google Earth за допомогою комп'ютерної програми AutoCad. Було виконано масштабування та оцифрування контурів окремих елементів (будівель, доріг тощо), що дало змогу отримати в першому наближенні розподіл територій за типами покриття. За методом № 1 загальна площа будівель досліджуваного кварталу становить 2,16 га, тобто 29,9 \% його загальної площі (табл. 1). Дороги та пішохідні доріжки з асфальтовими покриттями займають 1,75 га (24,2 \%). Квартал має високий ступінь озеленення, площа водопроникних поверхонь становить 3,32 га (45,9\%).

Табл. 1. Розподіл площ покриття житлового кварталу

\begin{tabular}{|c|c|c|c|c|c|c|c|}
\hline \multirow[b]{2}{*}{ 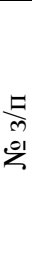 } & \multirow[b]{2}{*}{ Тип покриття } & \multicolumn{2}{|c|}{ Площа, м² } & \multicolumn{2}{|c|}{$\begin{array}{l}\text { Відносна } \\
\text { площа, \% }\end{array}$} & \multirow{2}{*}{ 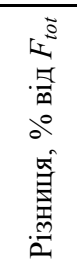 } & \multirow{2}{*}{ 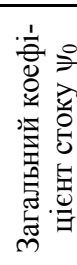 } \\
\hline & & $\begin{array}{c}\text { метод } \\
1\end{array}$ & $\begin{array}{c}\text { метод } \\
2\end{array}$ & $\begin{array}{c}\text { ме- } \\
\text { тод } 1\end{array}$ & $\begin{array}{c}\text { ме- } \\
\text { тод } 2\end{array}$ & & \\
\hline 1 & Дахи будівель & 21624 & 23230 & 29,90 & 32,12 & 2,22 & 0,7 \\
\hline 2 & $\begin{array}{l}\text { Штучні } \\
\text { водонепроникні } \\
\text { покриття доріг }\end{array}$ & 17537 & 16274 & 24,24 & 22,50 & $-1,75$ & 0,7 \\
\hline 3 & $\begin{array}{l}\text { Грунтові } \\
\text { покриття та зе- } \\
\text { лені насадження }\end{array}$ & 33172 & 32829 & 45,86 & 45,39 & $-0,47$ & 0,25 \\
\hline & Разом & 72333 & 72333 & 100 & 100 & & $\begin{array}{r}0,494 \\
0,496\end{array}$ \\
\hline
\end{tabular}
по вул. Широкій у м. Львові за методами № 1 та 2

Внаслідок проведення натурного обстеження території за методом № 2 було уточнено межі та типи покриттів кварталу, визначені за методом № 1 (див. табл. 1). Натурне обстеження дає змогу усунути похибки, що виникають внаслідок затінень чи спотворень на супутникових знімках, перекриття частини території зеленими насадженнями та ін. (Gironas et al., 2010). Отож, 
за методом № 2 отримано частку загальних водонепроникних покриттів $p_{t o t}=0,546$, що в межах похибки дорівнює результату $p_{t o t}=0,541$ за методом № 1 .

У другій частині натурного дослідження було встановлено особливості приєднання різних ділянок кварталу до централізованої мережі водовідведення (метод № $3)$. Цей метод дає змогу виконувати гідрологічний аналіз території басейну стоку, що охоплює шляхи збирання поверхневого стоку та його надходження до міської водовідвідної мережі. Кількісні результати аналізу типів покриття за методом № 3 зведено в табл. 2, а їхню графічну інтерпретацію зображено на рис. 1. Встановлення особливостей приєднання різних ділянок до мережі водовідведення за методом № 3 допомогло отримати частку ефективних водонепроникних покриттів $p_{e f f}=0,394$, що в 1,39 раза менше за частку загальних водонепроникних покриттів цього кварталу $p_{t o t}=0,546$.

Табл. 2. Розподіл площ покриття житлового кварталу по вул. Широкій у м. Львові за методом № 3 з урахуванням особливостей присднання до мережі каналізації

\begin{tabular}{|c|l|c|c|}
\hline $\begin{array}{c}\text { № } \\
\text { 3/п }\end{array}$ & \multicolumn{1}{|c|}{ Тип покриття } & $\begin{array}{c}\text { Пло- } \\
\text { ща, }\end{array}$ & $\begin{array}{c}\text { Відносна } \\
\text { площа, \% }\end{array}$ \\
\hline 1 & $\begin{array}{l}\text { Напряму приєднані водонепроник- } \\
\text { ні покриття доріг }\end{array}$ & 10300 & 14,24 \\
\hline 2 & $\begin{array}{l}\text { Неприєднані водонепроникні пок- } \\
\text { риття доріг }\end{array}$ & 5974 & 8,26 \\
\hline 3 & Напряму приєднані дахи будівель & 18170 & 25,12 \\
\hline 4 & Неприєднані дахи будівель & 5060 & 7,00 \\
\hline 5 & $\begin{array}{l}\text { Грунтові покриття та зелені наса- } \\
\text { дження }\end{array}$ & 32829 & 45,39 \\
\hline \multicolumn{2}{|r|}{ Разом } & 72333 & 100,00 \\
\hline
\end{tabular}

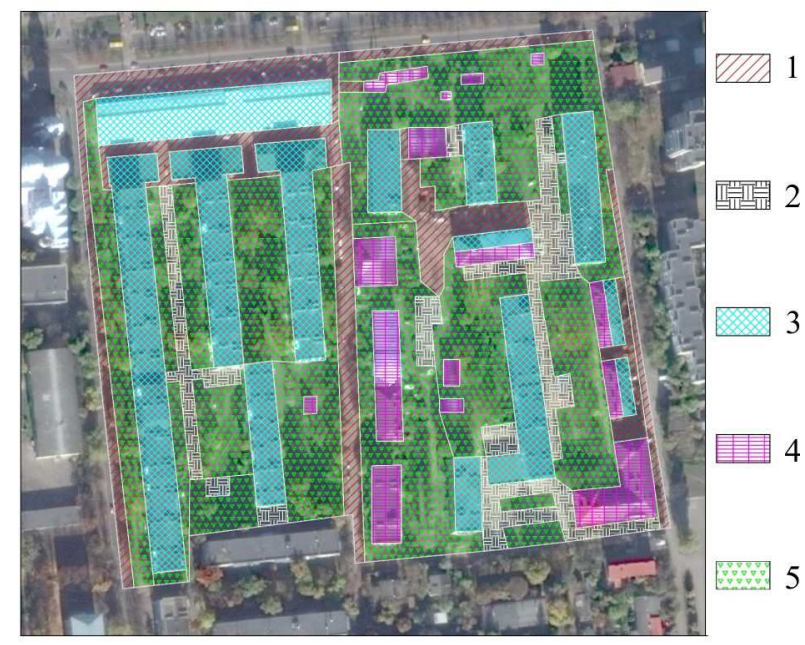

Рис. 1. Результати дослідження типів покриття житлового кварталу по вул. Широкій у м. Львові: 1,2 ) відповідно напряму приєднані та неприєднані вдосконалені покриття доріг;

$3,4)$ відповідно напряму приєднані та неприєднані дахи будівель; 5) грунтові покриття та зелені насадження

Відповідно до нормативних значень загального коефіцієнта стоку для різних типів покриття (Pravyla korystuvannia, 2008), для кварталу по вул. Широкій отримано середньозважені за площею значення загального коефіцієнта стоку за трьома описаними вище методами. За методами № 1 і 2 отримано значення $\psi_{0}=0,494$ та $\psi_{0}=0,496$, відповідно. 3 урахуванням ефективних водонепроникних покриттів за методом № 3 значення загального коефіцієнта стоку становить $\psi_{0}=0,427$, що в 1,16 раза менше, ніж за методом № 2. Оскільки об'єм дощового стоку прямо пропорційний до значення загального коефіцієнта стоку, врахування особливостей приєднання водонепроникних покриттів до водовідвід- ної мережі істотно впливає на значення розрахункових об'ємів та витрат дощового стоку з урбанізованих територій.

Графіки взаємозв'язків між частками ефективних $p_{\text {eff }}$ та загальних $p_{t o t}$ водонепроникних покриттів за даними (Alley \& Veenhuis, 1983) та (Yang et al., 2011), а також отриманий в роботі результат для житлового кварталу по вул. Широкій у м. Львові, наведено на рис. 2. За значення частки загальних водонепроникних покриттів $p_{t o t}=0,546$ внаслідок проведеного натурного обстеження житлового кварталу отримано частку ефективних водонепроникних покриттів $p_{\text {eff }}=0,394$. Це в 1,08 раза менше, ніж за формулою (1), отриманою для м. Денвер, та в 1,18 раза менше, ніж на формулою (2) для Маріон Каунті. 3 метою отримання для м. Львова достовірної залежності, аналогічної до степеневих формул (1) і (2), необхідно виконати подібні дослідження щонайменше для 20 інших кварталів для того, щоб отримати статистично значущу узагальнену залежність між частками ефективних та загальних водонепроникних покриттів.

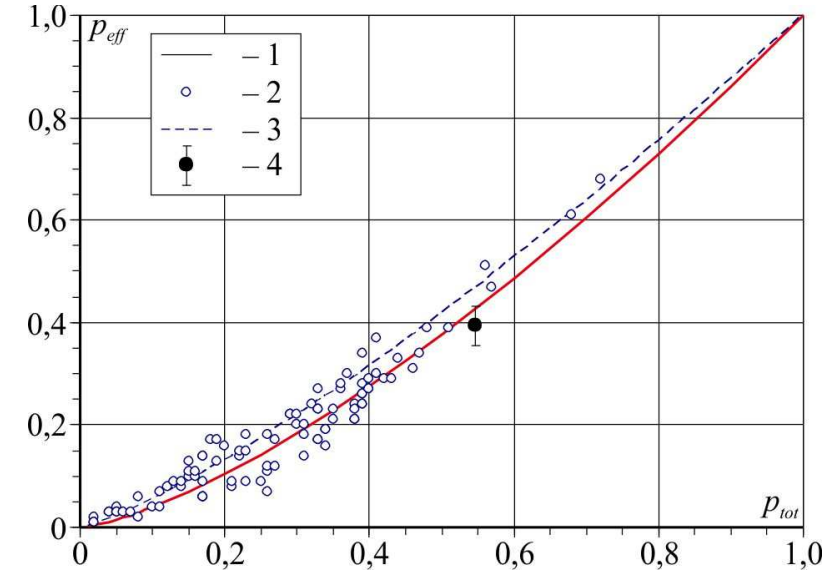

Рис. 2. Взаємозв'язки між частками ефективних та загальних водонепроникних покриттів: 1) степенева апроксимація результатів для м. Денвер (Alley \& Veenhuis, 1983); 2, 3) відповідно результати для Маріон Каунті (Yang et al., 2011) та їх степенева апроксимація (2); 4) досліджуваний квартал м. Львова

Висновки. Підтверджено важливість поділу загальних водонепроникних покриттів на напряму приєднані до міської каналізаційної мережі (ефективні) водонепроникні покриття та не приєднані водонепроникні покриття. Порівняно розподіл площ із різними типами покриття для житлового кварталу по вул. Широкій у м. Львові за трьома описаними в роботі методами. За методами № 1 і 2 отримано значення загального коефіцієнта стоку $\psi_{0}=0,494$ та $\psi_{0}=0,496$ відповідно, а з урахуванням ефективних водонепроникних покриттів за методом № $3-\psi_{0}=0,427$. За значення частки загальних водонепроникних покриттів $p_{t o t}=0,546$ внаслідок проведеного натурного обстеження житлового кварталу за методом № 3 отримано частку ефективних водонепроникних покриттів $p_{\text {eff }}=0,394$, що в 1,08 раза менше, ніж за формулою (1), отриманою для Денвера, та в 1,18 раза менше, ніж на формулою (2) для території Маріон Каунті.

\section{Перелік використаних джерел}

Alley, W. M., \& Veenhuis, J. E. (1983). Effective impervious area in urban runoff modeling. J. Hydraul. Eng., 109(2), 313-319. https://doi.org/10.1061/(ASCE)0733-9429(1983)109:2(313)

Gironas, J., Niemann, J. D., Roesner, L. A., Rodriguez, F., \& Andrieu, H. (2010). Evaluation of methods for representing urban terrain in 
storm-water modeling. Journal of Hydrological Eng., 15(1), 1-14. https://doi.org/10.1061/(ASCE)HE.1943-5584.0000142

James, W., \& Rossman, L. (2010). Water systems models User's guide to SWMM 5. (13th ed.). Ontario: CHI Press Publication, $905 \mathrm{p}$.

Laconte, P., \& Gossop, C. (2016). Sustainable cities: Assessing the performance and practice of urban environments. I. B. Tauris, $242 \mathrm{p}$.

Lee, J. G., \& Heaney, J. P. (2003). Estimation of Urban Imperviousness and its impacts on storm water systems. Journal of Water Resources Planning and Management, 129(5), 419-426. https://doi.org/10.1061/(ASCE)0733-9496(2003)129:5(419)

Pravyla. (2008). Pravyla korystuvannia systemamy tsentralizovanoho komunalnoho vodopostachannia ta vodovidvedennia $v$ naselenykh punktakh Ukrainy. Kyiv: Minzhytlokomunhosp Ukrainy, 29 p. [In Ukrainian].

Sanzana, P., Gironas, J., Braud, I., et al. (2017). A GIS-based urban and Peri-urban landscape representation toolbox for hydrological distributed modelling. Environmental Modelling and Software, 91, 168-185. https://doi.org/10.1016/j.envsoft.2017.01.022

Tkachuk, S. H., \& Zhuk, V. M. (2012). Rehuliuvannia doshchovoho stoku $v$ systemakh vodovidvedennia: monohrafiia. Lviv: Vyd-vo Lvivskoi Politekhniky, 216 p. [In Ukrainian].

Yang, G., Bowlinga, L. C., Cherkauer, K. A., \& Pijanowski, B. C. (2011). The impact of urban development on hydrologic regime from catchment to basin scales. Landscape and Urban Planning, 103, 237-247. https://doi.org/10.1016/j.landurbplan.2011.08.003

Zhuk, V. (2018). Statistical method for determining the distribution of surfaces by type of coverage on large urbanized drainage basins. Instal, 3(393), 45-48.

Zhuk, V. M., \& Matlai, I. I. (2010). Metody rozrakhunku obiemu doshchovoho stoku. Bulletin of the National University "Lviv Polytechnic". Series: Teploenerhetyka. Inzheneriia dovkillia. Avtomatyzatsiia, 677, 32-38. [In Ukrainian].

В. М. Жук, Л. И. Вовк, И. И. Матлай, И. Ю. Попадюк Национальный университет "Львовская политехника", г. Львов, Украина

\section{ВЗАИМОСВЯЗЬ МЕЖДУ ОБЩИМИ И ЭФФЕКТИВНЫМИ ВОДОНЕПРОНИЦАЕМЫМИ ПОКРЫТИЯМИ ПРИ МОДЕЛИРОВАНИИ ДОЖДЕВОГО ВОДООТВЕДЕНИЯ}

На примере жилого квартала по ул. Широкой во Львове подтверждена важность разделения общих водонепроницаемых покрытий на напрямую присоединенные к городской канализационной сети (эффективные), водонепроницаемые покрытия и неприсоединенные водонепроницаемые покрытия. На основе анализа и обобщения результатов исследования микрорайонов Денвера (США) (Alley \& Veenhuis, 1983) и территории Марион Каунти (США) (Yang, Bowling, Cherkauer \& Pijanowski, 2011) получены обобщенные степенные зависимости долевого участия эффективных водонепроницаемых покрытий $p_{\text {eff }}$ от долевого участия общих водонепроницаемых покрытий $p_{t o t}$. Для жилого квартала по ул. Широкой во Львове выполнены исследования распределения покрытий с использованием трех методов: камеральный анализ распределения поверхностей по типам покрытия на базе спутниковых изображений местности; натурное обследование территории квартала с уточнением границ покрытий различных типов; натурное обследование с установлением особенностей присоединения различных участков к централизованной сети водоотведения. Выполнено сравнение распределения площадей с различными типами покрытия и значений общего коэффициента стока $\psi_{0}$, полученных с использованием трех описанных в работе методов. В результате натурного обследования жилого квартала Львова при значении долевого участия общих водонепроницаемых покрытий $p_{t o t}=0,546$ долевое участие эффективных водонепроницаемых покрытий составило $p_{e f f}=0,394$, что в 1,08 и в 1,18 раз меньше, чем по формулам, полученным соответственно для Денвера и территории Марион Каунти.

Ключевые слова: поверхностный сток; общие водонепроницаемые покрытия; эффективные водонепроницаемые покрытия; общий коэффициент стока.

V. M. Zhuk, L. I. Vovk, I. I. Matlai, I. Yu. Popadiuk Lviv Polytechnic National University, Lviv, Ukraine

\section{CORRELATION BETWEEN THE TOTAL AND EFFECTIVE IMPERVIOUSNESS IN STORMWATER} MODELLING

The paper presents a case study for the residential quarter at Shyroka Street in Lviv City. The importance of the division of the general impervious covers onto the directly connected to the urban drainage network (effective) impervious surfaces and unconnected impervious surfaces is confirmed in the paper. Using the results of the researches in Denver City and Marion County (USA), generalized power-law dependences between the effective imperviousness $p_{\text {eff }}$ and the total imperviousness $p_{t o t}$ are obtained. The investigation of the distribution of cover types for residential quarter at Shyroka Street in Lviv City was performed using three methods: the analysis of the surface type distribution on the basis of satellite images of the terrain (method No. 1); field survey of the territory of the quarter with the specification of the boundaries of different cover types (method No. 2); field survey with the establishment of the peculiarities of the connection of different sites to the centralized drainage network (method No. 3). The share of the total impervious covers, obtained by the method No. $2 p_{\text {tot }}=0.546$, is equal within the error range to the result $p_{\text {tot }}=0.541$, obtained by the method \# 1 . The share of the effective impervious covers, $p_{\text {eff }}=0.394$, obtained by the method \# 3 is 1.39 times less than the share of total impervious covers in the quarter $p_{t o t}=0.546$. The value of the general runoff coefficient is almost the same using the methods No. 1 and No. $2\left(\psi_{0}=0.494\right.$ and $\psi_{0}=0.496$ respectively), instead much less value $\psi_{0}=0.427$ is obtained in the method No. 3. In a result of a full-scale survey of the residential quarter in Lviv City, the effective imperviousness is $p_{e f f}=0.394$. This value is 1.08 times less comparing to the result of calculation using the power-law formula for Denver City and 1.18 times less comparing to the formula for Marion County. It is necessary to gain the similar results of field investigation for at least 20 quarters in order to obtain reliable power-law dependence between the effective and total imperviousness for Lviv City.

Keywords: surface runoff; total imperviousness; effective imperviousness; general runoff coefficient. 